\title{
Terapeutisk komplementhemming - fra eksperimentell til klinisk medisin
}

\author{
Komplementsystemet er sentralt i infeksjonsforsvaret, men det deltar \\ også i den generelle vevshomøostasen. Ved flere sykdommer skjer \\ det en uhensiktsmessig aktivering av systemet, derfor er hemming \\ av komplementsystemet blitt et interessant behandlingsalternativ ved \\ flere ulike tilstander.
}

Komplementsystemet tilhører vårt medfødte immunapparat. Det beskytter oss mot infeksjoner ved å gjenkjenne mikrobestrukturer. De senere års forskning har imidlertid vist at komplementsystemet spiller en sentral rolle også i den generelle vevshomøostasen, i nært samarbeid med en rekke biologiske systemer, og at det er involvert i patofysiologien ved en lang rekke sykdomsprosesser.

Hemming av komplementaktivering er derfor blitt en interessant behandlingstilnærming ved flere sykdommer. I denne artikkelen gis en kortfattet oversikt over komplementsystemet, hvordan komplementhemmere brukes i dag og hvordan de kan tenkes brukt i fremtiden.

\section{Komplementsystemet}

Komplementsystemet (1-3) er et av kroppens kaskadesystemer og består av flere titalls proteiner (fig 1). Den ene delen av systemet består av en rekke plasmaproteiner som aktiveres i en bestemt rekkefølge og danner aktiveringsprodukter med ulike funksjoner. Den andre delen er membranproteiner som fungerer som reseptorer for aktiveringsproduktene. En lang rekke av proteinene er reguleringsproteiner som sørger for å holde systemet under kontroll, hvorav faktor $\mathrm{H}$ (FH) er av vesentlig betydning.

Det er tre hovedveier for aktivering.

Klassisk aktivering. Her binder $\mathrm{C} 1 \mathrm{q}$ antistoffer eller andre molekyler, for eksempel C-reaktivt protein, som er bundet på en overflate. Dette fører til aktivering av C1r og $\mathrm{C} 1 \mathrm{~s}$, som igjen aktiverer $\mathrm{C} 4$ og $\mathrm{C} 2$ med påfølgende aktivering av $\mathrm{C} 3$, som da spaltes i C3a og C3b. C3a har både pro- og antiinflammatoriske effekter, mens $\mathrm{C} 3 \mathrm{~b}$ er et viktig opsonin ved å binde kovalent til en overflate.

Lektinaktivering. Dette skjer når for eksempel mannosebindende lektin (MBL) eller fikoliner reagerer med mikrober eller skadet vev, men også når naturlig forekommende IgM-antistoffer reagerer med kroppsegne strukturer. Dette aktiverer mannoseassosierte serinproteaser (MASP1 og MASP2), som er analoger til $\mathrm{C} 1 \mathrm{r}$ og $\mathrm{C} 1 \mathrm{~s}$ i klassisk vei og som igjen aktiverer $\mathrm{C} 4$. Videre er aktiveringen lik den som skjer i klassisk vei. C1-inhibitor (C1-INH) og C4b-bindende protein (C4BP) er viktige regulatorer av både klassisk aktivering og lektinaktivering.

Alternativ aktivering. Dette skjer under fysiologiske forhold ved spontan hydrolyse av C3-molekylet, som imidlertid holdes under kontroll av faktor I (FI) og faktor $\mathrm{H}$ (FH). Under ufysiologiske forhold, for eksempel ved blodets kontakt med en fremmed overflate, forrykkes denne likevekten og alternativ vei forsterker aktiveringen ved hjelp av faktor B (FB), faktor D (FD) og properdin (FP). C5 spaltes til C5a og C5b. C5a er et meget potent peptid, med en rekke effekter i den inflammatoriske prosessen. $\mathrm{C} 5 \mathrm{~b}$ reagerer med $\mathrm{C} 6, \mathrm{C} 7, \mathrm{C} 8$ og $\mathrm{C} 9$ og danner det terminale C5b-9 komplementkompleks (TCC), som finnes i en membranbundet form som kan gi lyse, spesielt av Neisseria-bakterier og røde blodceller, og i en løselig form (sC5b-9) som kan måles i plasma og er en markør for komplementaktivering. sC5b-9 binder regulatorene vitronectin (VN) og clusterin (CL) som gjør at dette komplekset forblir i flytende form.

På overflaten av kroppens celler finnes det en rekke komplementreseptorer. Disse er av tre ulike kategorier. Noen gir cellene signaler som aktiverer dem, for eksempel C5areseptorer, som stimuleres til inflammatorisk respons av det biologisk aktive $\mathrm{C} 5 \mathrm{a}-$ peptidet. Andre er fagocytosereseptorer (f.eks. CR3; CD11b/CD18), mens den tredje gruppen har en viktig funksjon i å beskytte cellene mot angrep fra eget komplement.

Den overordnede funksjonen til komplement er nettopp å utløse en inflammatorisk reaksjon som ledd i bekjempelsen av mikrober (infeksiøst betinget inflammasjon) og i vevsregenerering etter skade uten at mikrober er til stede (steril inflammasjon). Aktiveringen er underlagt meget streng kontroll ved hjelp av regulatorer både i væskefasen og på celleoverflaten for å unngå at systemet skal aktiveres uhensiktsmessig og gi vevsskade og sykdom. Reseptorene CR1, MCP/ CD46 og DAF/CD55 er viktige hemmere på
Knut Tore Lappegård

knut.tore.lappegard@gmail.com

Medisinsk divisjon

Nordlandssykehuset Bodø

og

Institutt for klinisk medisin

Universitetet i Troms $\emptyset$

Anna Bjerre

Barnemedisinsk avdeling

Kvinne- og barneklinikken

Oslo universitetssykehus

Geir Erland Tjønnfjord

Avdeling for blodsykdommer

Oslo universitetssykehus

og

Institutt for klinisk medisin

Universitetet i Oslo

Tom Eirik Mollnes

Forskningslaboratoriet

Nordlandssykehuset Bodø

og

Senter for molekylær inflammasjonsforskning (SFF-CEMIR)

Norges teknisk-naturvitenskapelige universitet

IR Engelsk oversettelse på www.tidsskriftet.no

\section{HOVEDBUDSKAP}

Komplementsystemet er involvert i en rekke sykdomsprosesser

Hemming av komplementsystemet står sentralt i behandlingen av paroksystisk nattlig hemoglobinuri og atypisk hemolytisk uremisk syndrom

Komplementhemming kan være aktuelt også ved flere andre tilstander 


\section{KOMPLEMENTSYSTEMET}

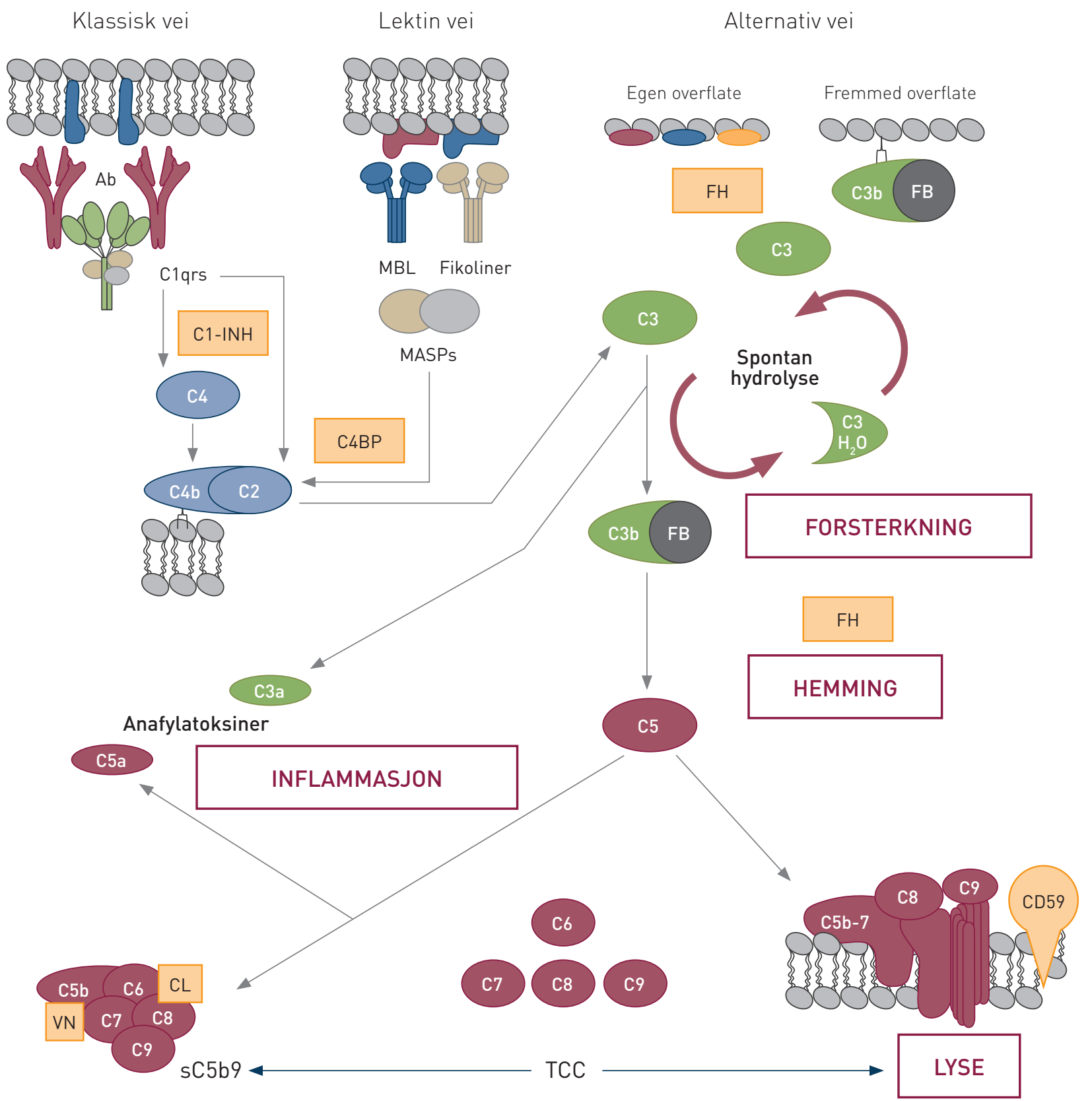

Figur 1 En forenklet fremstilling av komplementsystemets tre aktiveringsveier og hvordan disse konvergerer i C3 og deretter i C5, som så spaltes i C5a og C5b. C5a er et potent anafylatoksin, mens C5b inngår i det terminale komplementkomplekset. Omarbeidet etter originalfigur av Tom Eirik Mollnes

C3-nivå, mens CD59 hemmer inkorporering av C5b-9 i membranen. Pasienter med paroksystisk nattlig hemoglobinuri $(\mathrm{PNH})$ mangler DAF- og CD59-reseptor på celleoverflaten, og de røde blodcellene lyseres da av komplement (fig 2).

\section{Komplementaktivering og sykdom}

Komplementsystemet samarbeider tett med kroppens øvrige kaskadesystemer: koagulasjon, fibrinolyse og kallikrein-kinin-systemene. For eksempel deltar C1-inhibitor i regu- leringen av alle disse systemene. Genetisk mangel på C1-inhibitor gir angioødem, og C1inhibitor har vært brukt som behandling under anfall ved hereditært angioødem i flere tiår. Patogenesen ved sykdommen er imidlertid ikke komplementmediert, men skyldes bradykininfrigjøring (4). C1-inhibitor er altså ikke en spesifikk komplementhemmer og vil derfor ikke bli nærmere omtalt her.

Som for alle kaskadesystemene har komplement sin primære funksjon lokalt, mens systemisk aktivering er uhensiktsmessig og kan i verste fall være fatalt. Både lokal og systemisk komplementaktivering er vist ved en lang rekke andre sykdomstilstander, men hvorvidt komplementaktiveringen har patogenetisk betydning eller kun er en markør på den pågående inflammasjonsprosessen, er ofte uklart.

\section{Prinsipper for komplementhemming} Tre sentrale spørsmål er utgangspunkt for hvilken strategi man skal velge for blokkering av komplementsystemet $(1,5)$.

Hvor $i$ kaskaden vil man angripe? Man 
kan spesifikt blokkere starten i en av de tre aktiveringsveiene hvis patogenesen er kartlagt og kun en av veiene er involvert, for eksempel C1 i klassisk vei, MBL i lektin vei eller faktor D i alternativ vei.

Hvis flere av veiene er involvert, kan man blokkere et av de sentrale felles molekylene - C3 dersom man ønsker en kraftig blokkering tidlig i kaskaden (6) eller $\mathrm{C} 5$ om man kun ønsker å hindre C5a- og C5b-9-danning (7). Alternativt kan man blokkere et spesifikt aktiveringsprodukt eller en reseptor, for eksempel C5a eller C5a-reseptor 1 (C5aR1).

Hva slags type hemmer vil man bruke? Mest aktuelt er småmolekylære peptider, som er enkelt og billig å fremstille. Disse har ofte kort halveringstid, men kan kobles til større molekyler, for eksempel et immunglobulinfragment, eller utrustes med et sete som binder albumin etter at det er injisert og slik øke halveringstiden betydelig.

Alternativt kan man lage større rekombinante proteiner som hemmer komplement eller benytte seg av monoklonale antistoffer som blokkerer komplementkomponenter eller reseptorer (8).

Vil man hemme systemisk eller lokalt? Systemisk hemming vil påvirke hele kroppens komplementsystem, mens lokal hemming er organrettet. $\AA$ hemme systemisk på tidlig nivå, for eksempel blokkere $\mathrm{C} 3$, vil trolig bety betydelig økt infeksjonsfare, siden opsonisering er den viktigste mekanismen komplement har i infeksjonsforsvaret. Systemisk C5-hemming gir betydelig mindre risiko for infeksjon.

Lokalbehandling kan gjøres med for eksempel øyedråper eller injeksjon i øyet ved aldersrelatert maculadegenerasjon (AMD) (9). Alternativt kan man koble hemmeren til et målsøkende molekyl som binder vevsspesifikt, for eksempel i ledd, og dermed oppsøker og slår seg ned der man ønsker hemmingen.

\section{Komplementhemmer i bruk i dag}

Det monoklonale antistoffet eculizumab er det eneste spesifikke komplementhemmende legemidlet som er godkjent av de europeiske legemiddelmyndigheter (EMA). Det har foreløpig bare to indikasjoner: paroksystisk nattlig hemoglobinuri og atypisk hemolytisk uremisk syndrom (aHUS).

Ved paroksystisk nattlig hemoglobinuri mangler DAF og CD59 på celleoverflaten, de røde blodcellene blir derfor sårbare overfor komplementmediert lyse (10). Eculizumab hindrer komplementmediert lyse av de røde blodcellene ved denne tilstanden (fig 2), ved atypisk hemolytisk uremisk syndrom hemmer det inflammasjonsreaksjonen, i begge tilfeller ved å blokkere den terminale kaskadereaksjonen på C5-nivå. En rekke andre komplementhemmere er under preklinisk og fase 1-utprøvning (tab 1).

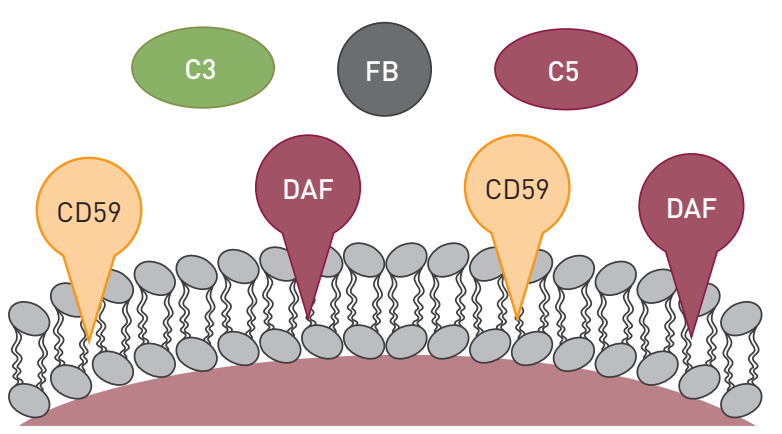

Normal erytrocytt beskyttet mot komplement

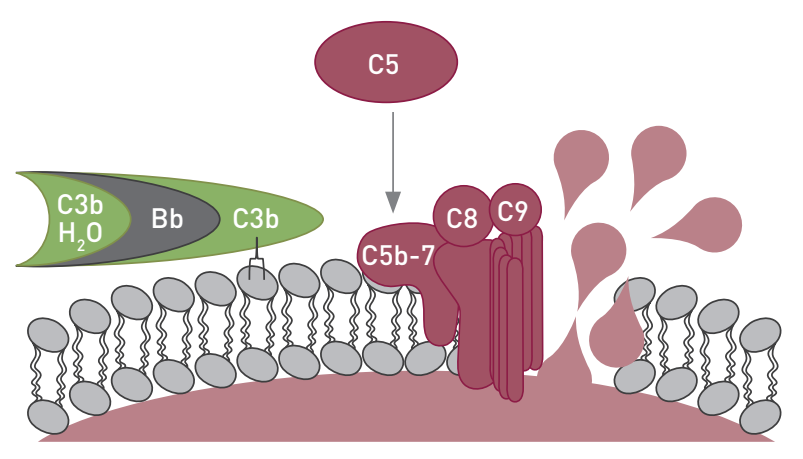

Hemolyse av PNH-erytrocytt

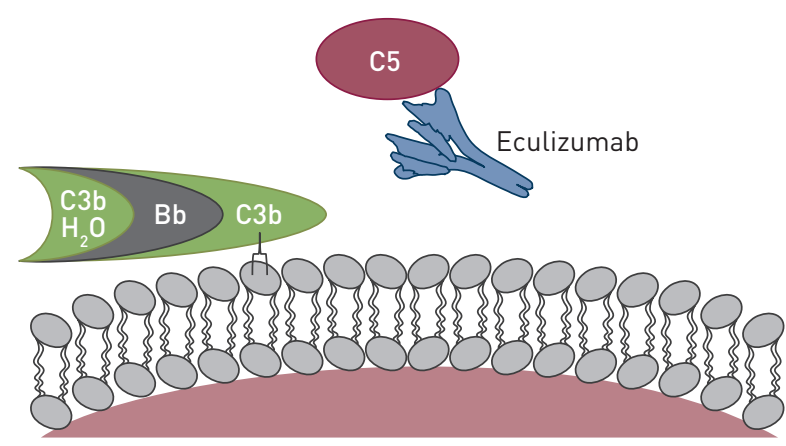

PNH-erytrocytt beskyttet av eculizumab

Figur 2 En skjematisk fremstilling av hvordan eculizumab beskytter erytrocytten mot lyse ved paroksysmal nattlig hemoglobinuri. Omarbeidet etter originalfigur av Tom Eirik Mollnes

I Norge ble eculizumab første gang brukt til behandling av en pasient med paroksystisk nattlig hemoglobinuri i 2008, og per 15.8. 2015 er det 20 pasienter (16 med paroksystisk nattlig hemoglobinuri og fire med atypisk hemolytisk uremisk syndrom) som er under pågående behandling (G.E. Tjønnfjord, personlig meddelelse). For paroksystisk nattlig hemoglobinuri er det utarbeidet egne nasjonale retningslinjer for diagnostikk og behandling (11). Behandlingen er forbeholdt pasienter med den alvorligste kliniske fenotypen.

Det er ikke utarbeidet egne nasjonale ret- ningslinjer for behandling av atypisk hemolytisk uremisk syndrom, men det foreligger en internasjonal konsensusrapport (12). Det er i hovedsak to scenarioer hvor behandling med eculizumab er aktuelt på grunn av genetisk defekt i komplementsystemet: for å hindre eller forsinke utvikling til dialysekrevende nyresvikt og for å forebygge residiv etter nyretransplantasjon (13). Eculizumab kan også benyttes ved atypisk hemolytisk uremisk syndrom forårsaket av autoantistoffer mot komplementfaktor $\mathrm{H}$, men i de fleste tilfeller vil terapien ved denne tilstanden først og fremst være rettet mot vedlikeholds- 
Tabell 1 Noen utvalgte eksempler på komplementhemmere i bruk og under utprøvning

\begin{tabular}{|c|c|c|c|}
\hline Navn & Type & Angrepspunkt & Indikasjon/mulig bruk \\
\hline Eculizumab & Monoklonalt antistoff & C5 & $\begin{array}{l}\text { Paroksystisk nattlig hemoglobinuri, } \\
\text { atypisk hemolytisk uremisk syndrom }\end{array}$ \\
\hline Compstatin & Peptid & $\mathrm{C} 3$ & $\begin{array}{l}\text { Paroksystisk nattlig hemoglobinuri, atypisk } \\
\text { hemolytisk uremisk syndrom, dense deposit } \\
\text { disease, aldersrelatert maculadegenerasjon }\end{array}$ \\
\hline NM9401 & Monoklonalt antistoff & Properdin & $\begin{array}{l}\text { Atypisk hemolytisk uremisk syndrom, } \\
\text { dense deposit disease }\end{array}$ \\
\hline TNX-234 & Monoklonalt antistoff & Faktor D & Aldersrelatert maculadegenerasjon \\
\hline TA106 & Monoklonalt antistoff & Faktor B & Aldersrelatert maculadegenerasjon, astma \\
\hline TNT003 & Monoklonalt antistoff & $\mathrm{C} 1 \mathrm{~s}$ & Kuldeagglutininsyndrom \\
\hline NN8209/NN8210 & Monoklonalt antistoff & C5a-reseptor & Revmatoid artritt \\
\hline NOX-D19 & Aptamer (RNA som binder protein) & $\mathrm{C} 5 \mathrm{a}$ & Transplantasjoner \\
\hline AMY_301 & Peptid & Binder faktor $\mathrm{H}$ til biomaterialoverflater & Preklinisk \\
\hline Complin & Peptid & C2 og faktor B & Preklinisk \\
\hline PIC1 & Peptid & $\mathrm{C} 1$ & $\begin{array}{l}\text { Transplantasjoner, akutt intravaskulær } \\
\text { hemolytisk transfusjonsreaksjon }\end{array}$ \\
\hline SiRNA & Små, inhiberende RNA-deler & C2 og flere andre aktuelle angrepspunkter & Preklinisk \\
\hline
\end{tabular}

behandling med sikte på å holde anti-H-titeret under kontroll (14).

\section{Kontrollerte kliniske studier - og mangel på slike}

For paroksystisk nattlig hemoglobinuri er det gjort én placebokontrollert studie med eculizumab der grad av hemolyse og behov for transfusjoner var endepunkter (7). Transfusjonsbehovet gikk ned ved eculizumabbehandling. Det er gjort ikke-placebokontrollerte studier på sikkerhet og effekt $(15$, 16). Dessuten foreligger det studier med overlevelse som endepunkt med sammenlikning mot historiske kontrollpersoner, der bruk av eculizumab var assosiert med redusert dødelighet (17).

For atypisk hemolytisk uremisk syndrom er det ikke gjort randomiserte, placebokontrollerte studier, men det foreligger flere studier der effekt på endepunkter som nyrefunksjon og proteinuri er dokumentert $(13,18)$. En rekke kasuistikker og serier med noen få pasienter har vist meget god effekt, noe som sammen med sykdommens sjeldne forekomst har lagt grunnlaget for myndighetenes godkjenning (19).

Innen feltet iskemisk hjertesykdom foreligger det flere randomiserte, placebokontrollerte studier med komplementhemmeren pexelizumab, som var forgjengeren til eculizumab. Pexelizumab ble i store studier sammenliknet med placebo ved hjerteinfarkt og ulike former for hjertekirurgi. Studiene viste ingen forskjell mellom behandlingsgruppene når det gjaldt de primære endepunktene. En etteranalyse av disse studiene antyder dog at preparatet kanskje ikke var gitt $i$ optimal dose og på optimalt tidspunkt (20). Produsenten hadde imidlertid på dette tidspunkt avsluttet forsøkene med pexelizumab ved iskemisk hjertesykdom og konsentrerte seg om eculizumab med indikasjonene paroksystisk nattlig hemoglobinuri, atypisk hemolytisk uremisk syndrom og andre sjeldne sykdommer (tab 1).

\section{Mulige fremtidige indikasjoner}

Også ved nyresykdommen C3-glomerulopati (C3GN) (13) (inkludert dense deposit disease, DDD) (21), antistoffmediert akutt avstøtning av transplantert nyre (21), alvorlig antifosfolipidsyndrom (22), vaskulitt assosiert med antinøytrofile cytoplasmatiske antistoffer (ANCA) (23), myasthenia gravis (24) og neuromyelitis optica (25) har komplementhemming vist noe effekt, men indikasjonene er uavklart. I tillegg pågår studier innenfor så varierte områder som sepsis, obstruktiv lungesykdom, inflammatorisk tarmsykdom og ulike former for iskemireperfusjonsskade (5). Også ved noen former for autoimmun hemolytisk anemi og ved akutte hemolytiske transfusjonsreaksjoner er det mulig at komplementhemming kan ha en plass $(26,27)$.

I dyremodeller har man lovende resultater med komplementhemmere koblet til antistoffer med spesiell affinitet for molekyler i et ledd med artritt eller ved å injisere en DNA-vektor som koder for produksjonen av et C5-blokkerende miniantistoff, slik at man får lokal produksjon i det affiserte leddet (28). Det gjenstår å se om slik målrettet terapi i fremtiden vil kunne brukes klinisk til behandling av leddgikt og andre tilstander med komplementindusert vevsdestruksjon.

\section{Bivirkninger}

Pasienter med medfødt mangel på C5 eller en annen terminal komponent er stort sett friske, men de har økt risiko for å få Neisseria-infeksjon, fordi drap av disse bakteriene skjer spesielt av C5b-9. Systemisk C5-hemming vil gi tilsvarende risiko. Pasientene må derfor vaksineres mot Neisseria meningitidis (29). Utover risikoen for Neisseria-infeksjon synes ikke behandling med eculizumab så langt å være forbundet med noen fare (17).

Bivirkninger av komplementhemmere vil man trolig kun se ved vedvarende systemisk behandling (30). Risikoen for infeksjon må antas å være stor ved systemisk behandling på C3-nivå, siden C3-defekter ofte er assosiert med infeksjonssykdom (31). Spesifikk hemming av C5a (med antistoff eller reseptorblokker) bevarer C5b-9-danningen, dermed er forsvaret mot Neisseria intakt (32). Behandling av sykdommer med målrettet organspesifikk terapi hvor systemisk komplement ikke hemmes, vil neppe medføre bivirkninger, i alle fall er det ikke observert slikt i dyreforsøk (28). 


\section{Oppsummering}

Internasjonalt er bruk av det C5-blokkerende monoklonale antistoffet eculizumab på få år blitt førstevalget ved behandling av atypisk hemolytisk uremisk syndrom og de alvorligste fenotypene av paroksystisk nattlig hemoglobinuri. Eculizumab er foreløpig den eneste komplementhemmeren i vanlig klinisk bruk.

Dette har skjedd til tross for at det bare foreligger én randomisert, placebokontrollert studie om eculizumab ved paroksystisk nattlig hemoglobinuri og ingen for atypisk hemolytisk uremisk syndrom, og at behandlingen er meget kostbar. Det er grunn til å tro at komplementhemming som terapi vil øke i fremtiden og at også andre preparater vil vise seg å være effektive.

\section{Knut Tore Lappegård (f. 1961)}

er spesialist i indremedisin, overlege og professorll.

Forfatter har fylt ut ICMJE-skjemaet og oppgir ingen interessekonflikter.

\section{Anna Bjerre (f. 1957)}

er dr.med., spesialist i pediatri og seksjonsoverlege for pediatrisk nefrologi.

Forfatter har fylt ut ICMJE-skjemaet og oppgir ingen interessekonflikter.

\section{Geir E. Tjønnfjord (f. 1953)}

er og spesialist i indremedisin og i blodsykdommer, avdelingsleder og professor i hematologi. Forfatter har fylt ut ICMJE-skjemaet og oppgir følgende interessekonflikt: Han har mottatt honorar fra Alexion Pharma Nordics.

\section{Tom Eirik Mollnes (f. 1956)}

er forsker og professor II ved Universitetet i Tromsø og Universitetet i Oslo.

Forfatter har fylt ut ICMJE-skjemaet og oppgir ingen interessekonflikter.

\section{Litteratur}

1. Ricklin D, Lambris JD. Complement in immune and inflammatory disorders: pathophysiological mechanisms. J Immunol 2013; 190: 3831-8.
2. Walport MJ. Complement. First of two parts. N Engl J Med 2001; 344: 1058-66.

3. Walport MJ. Complement. Second of two parts. N Engl J Med 2001; 344: 1140-4.

4. Nielsen EW. Hereditært angioødem. Tidsskr Nor Lægeforen 1989; 109: 1383-5.

5. Ricklin D, Lambris JD. Complement in immune and inflammatory disorders: therapeutic interventions. J Immunol 2013; 190: 3839-47.

6. Risitano AM, Ricklin D, Huang Y et al. Peptide inhibitors of $\mathrm{C} 3$ activation as a novel strategy of complement inhibition for the treatment of paroxysma nocturnal hemoglobinuria. Blood 2014; 123 2094-101.

7. Hillmen P, Young NS, Schubert J et al. The complement inhibitor eculizumab in paroxysmal nocturnal hemoglobinuria. N Engl J Med 2006; 355: 1233-43.

8. Melis JP, Strumane K, Ruuls SR et al. Complement in therapy and disease: regulating the complement system with antibody-based therapeutics. Mol Immunol 2015; 67: 117-30.

9. Troutbeck R, Al-Qureshi S, Guymer RH. Therapeutic targeting of the complement system in age-related macular degeneration: a review. Clin Experiment Ophthalmol 2012; 40: 18-26.

10. Nissen-Meyer LS, Tjønnfjord GE, Golebiowska E et al. Paroksysmal nattlig hemoglobinuri ved Oslo universitetssykehus 2000-10. Tidsskr Nor Legeforen 2015: 135: 1039-43.

11. Tjønnfjord EB, Tjønnfjord GE. Nasjonale retningslinjer for PNH. http://legeforeningen.no/ Fagmed/Norsk-selskap-for-hematologi/ Handlingsprogrammer/ (21.8.2015).

12. Loirat C, Fakhouri F, Ariceta $G$ et al. An international consensus approach to the management of atypical hemolytic uremic syndrome in children Pediatr Nephrol 2015. E-publisert 11.4.

13. Zuber J, Fakhouri F, Roumenina LT et al. Use of eculizumab for atypical haemolytic uraemic syndrome and C3 glomerulopathies. Nat Rev Nephrol 2012; 8: 643-57

14. Diamante Chiodini B, Davin JC, Corazza F et al. Eculizumab in anti-factor $h$ antibodies associated with atypical hemolytic uremic syndrome. Pediatrics 2014; 133: e1764-8

15. Brodsky RA, Young NS, Antonioli E et al. Multicenter phase 3 study of the complement inhibitor eculizumab for the treatment of patients with paroxysmal nocturnal hemoglobinuria. Blood 2008; 111: 1840-7

16. Kanakura Y, Ohyashiki K, Shichishima T et al. Longterm efficacy and safety of eculizumab in Japanese patients with PNH: AEGIS trial. Int J Hematol 2013 98: $406-16$

17. Hillmen P, Muus P, Röth A et al. Long-term safety and efficacy of sustained eculizumab treatment in patients with paroxysmal nocturnal haemoglobinuria. Br J Haematol 2013; 162: 62-73.

18. Vilalta R, Lara E, Madrid A et al. Long-term eculizumab improves clinical outcomes in atypical hemolytic uremic syndrome. Pediatr Nephrol 2012: 27: 2323-6

19. Fakhouri F, Frémeaux-Bacchi V, Loirat C. Atypical hemolytic uremic syndrome: from the rediscovery of complement to targeted therapy. Eur J Intern Med 2013; 24: 492-5

20. Martel C, Granger CB, Ghitescu M et al. Pexelizumab fails to inhibit assembly of the terminal complement complex in patients with ST-elevation myocardial infarction undergoing primary percutaneous coronary intervention. Insight from a substudy of the Assessment of Pexelizumab in Acute Myocardial Infarction (APEX-AMI) trial. Am Heart J 2012; 164: 43-51.

21. Ghirardo G, Benetti E, Poli F et al. Plasmapheresis-resistant acute humoral rejection successfully treated with anti-C5 antibody. Pediatr Transplant 2014; 18: E1-5.

22. Lonze BE, Zachary AA, Magro CM et al. Eculizumab prevents recurrent antiphospholipid antibody syndrome and enables successful renal transplantation. Am J Transplant 2014; 14: 459-65.

23. Charles Jennette J, Xiao H, Hu P. Complement in ANCA-associated vasculitis. Semin Nephrol 2013; 33: 557-64.

24. Kusner LL, Satija N, Cheng G et al. Targeting therapy to the neuromuscular junction: proo of concept. Muscle Nerve 2014; 49: 749-56.

25. Pittock SJ, Lennon VA, McKeon A et al. Eculizumab in AQP4-IgG-positive relapsing neuromyelitis optica spectrum disorders: an open-label pilot study. Lancet Neurol 2013; 12: 554-62.

26. Sharp JA, Whitley PH, Cunnion KM et al. Peptide inhibitor of complement $\mathrm{c} 1$, a novel suppressor of classical pathway activation: mechanistic studies and clinical potential. Front Immunol 2014; 5: 406

27. Shi J, Rose EL, Singh A et al. TNTO03, an inhibitor of the serine protease $\mathrm{C} 1 \mathrm{~s}$, prevents complement activation induced by cold agglutinins. Blood 2014 123: 4015-22.

28. Macor P. Durigutto P. De Maso L et al. Treatment of experimental arthritis by targeting synovial endothelium with a neutralizing recombinant antibody to C5. Arthritis Rheum 2012; 64: 2559-67.

29. Dmytrijuk A, Robie-Suh K, Cohen MH et al. FDA report: eculizumab (Soliris) for the treatment of patients with paroxysmal nocturnal hemoglobinuria. Oncologist 2008; 13: 993-1000.

30. Mollnes TE, Kirschfink M. Strategies of therapeutic complement inhibition. Mol Immunol 2006; 43: 107-21.

31. Falcão DA, Reis ES, Paixão-Cavalcante D et al. Deficiency of the human complement regulatory protein factor $\mathrm{H}$ associated with low levels of component C9. Scand J Immunol 2008; 68: 445-55.

32. Sprong T, Brandtzaeg P. Fung $M$ et al. Inhibition of $\mathrm{C} 5 \mathrm{a}$-induced inflammation with preserved $\mathrm{C} 5 \mathrm{~b}$ 9-mediated bactericidal activity in a human whole blood model of meningococcal sepsis. Blood 2003; 102: $3702-10$

Mottatt 13.1. 2015, første revisjon innsendt 21.6. 2015, godkjent 21.8. 2015. Redaktør: Lise Mørkved Helsingen. 